\title{
Paleomagnetic study of the Paleocene-Eocene Tarawan Chalk and Esna Shale: Dual polarity remagnetizations of Cenozoic sediments in the Nile Valley (Egypt)
}

\author{
Dennis V. Kent ${ }^{1,2}$ and Christian Dupuis ${ }^{3}$ \\ ${ }^{1}$ Department of Geological Sciences, Rutgers University, Piscataway, NJ 08854 \\ ${ }^{2}$ Lamont-Doherty Earth Observatory, Palisades, NY 10964 \\ email:dvk@rci.rutgers.edu \\ ${ }^{3}$ Géologie Fondamentale et Appliquée, Mons Polytechnics, Rue de Houdain, 9. B-7000 Mons, Belgium \\ email: christian.dupuis@fpms.ac.be
}

\begin{abstract}
A paleomagnetic study of the Paleocene-Eocene Esna Shale and Tarawan Chalk at the Dababiya and Qreiya sections near Luxor in central Egypt reveals stable normal and reverse polarity magnetizations. However, these (neritic) pelagic marine sediments have evidently been remagnetized because 1) the stable magnetizations are carried by hematite with no evidence of a primary magnetic mineral like magnetite, 2) the magnetic polarity stratigraphy is not consistent between the sections and with patterns expected from global magnetobiostratigraphic time scales, and 3) the directions correspond to late Cenozoic directions and are far from expected early Cenozoic reference directions for Africa. Our interpretation suggests that reported paleomagnetic results from other Cenozoic sediments from the Nile Valley suffered a similar fate. We suggest that the remagnetization may be associated with weathering and fluid flow during Neogene uplift and rifting in the formation of the early Nile Valley.
\end{abstract}

\section{INTRODUCTION}

Various criteria have been used to identify the specific level of the 55 Ma Paleocene/Eocene (P/E) boundary (Berggren and Aubry 1998) within magnetic Chron C24r (e.g., (Berggren et al. 1995); (Flynn and Tauxe 1998), one of the longest polarity intervals ( 2.5 m.y.) in the Cenozoic (Cande and Kent 1995). A Global Standard Stratotype-section and Point (GSSP) for the base of the Eocene Series (i.e., P/E boundary) has been proposed recently in the lowermost part of the Esna Shale at the Dababiya section in central Egypt (Aubry et al. 2002) (text-fig. 1). The Esna Shale and underlying Tarawan Chalk (Said 1990) were sampled in this section and a parallel section at Qreiya in an attempt to establish a magnetostratigraphic context for the sequence of events associated with the P/E boundary interval in Egypt. Unfortunately, both the Dababiya and Qreiya sections are remagnetized and no reliable magnetostratigraphy was recovered, even though normal and reverse polarities are present. A review of the literature suggests that bipolar remagnetizations have affected many Cenozoic sedimentary sections in the Nile Valley.

\section{GEOLOGIC SETTING AND SAMPLING}

The Dababiya section is well exposed in a large quarry and surrounding gebels near the village of Dababiya, about $23 \mathrm{~km}$ south of Luxor $\left(\right.$ Latitude $=25.50^{\circ} \mathrm{N}$, Longitude $=32.53^{\circ} \mathrm{E}$ ). The measured section is approximately $130 \mathrm{~m}$ thick and is composed of the basal Tarawan Chalk followed by a $\sim 120$ m-thick succession of the Esna Shale divided in three units. The Thebes Limestone overlies the Esna Shale. The zero-level of the section was measured from a distinctive cherty horizon within the Tarawan Chalk, approximately $10 \mathrm{~m}$ above the actual base of this unit and its contact with the underlying Dahkla Shale. The proposed $\mathrm{P} / \mathrm{E}$ boundary is located near the base of Calcareous nannofossil
Zone NP9b and marked by a sharp lithological transition from light-gray shale (Esna 1 unit, see Dupuis et al., this issue) to a dark carbonate-free clay-silt bed (base of the Esna 2 unit). This characteristic layer is followed by coprolite-bearing phosphatic laminite and shale then overlaid by a gray calcarenite (which may be traced into upper bathyal deposits in Egypt, Sinai Desert and Israel: Schmitz and Speijer 1996). These three main lithologies occur within the distinctive beds (Dababiya Quarry Beds) marking the base of the lower Esna 2 unit in the Esna Shale Formation at about the $14 \mathrm{~m}$ reference level or $7 \mathrm{~m}$ above the contact of the Esna Shale with the Tarawan Chalk. The remaining part of the succession is well exposed along the southern flank of the small gebel which dominates the quarry to the east and exhibits the Esna units 2 and 3 and the base of the Thebes Limestone.

The Qreiya section, exposed on the southeastern flank of Gebel Abu Had about $100 \mathrm{~km}$ northeast of Luxor (Latitude $=26^{\circ} 21^{\prime} \mathrm{N}$, Longitude $=33^{\circ} 01^{\prime} \mathrm{E}$ ), has nearly the same lithological succession as at Dababiya but is about a factor of two thinner. The Tarawan Chalk is about $8 \mathrm{~m}$ thick and the overlying Esna Shale is about $46 \mathrm{~m}$ thick, with a total thickness of $54 \mathrm{~m}$ compared to more than to $130 \mathrm{~m}$ at Dababiya. The zero-level of the measured section was at the basal contact of the Tarawan Chalk with the Dahkla Shale; the overlying Esna Shale is again capped by the Thebes Limestone. The P/E transition, defined by similar criteria as at Dababiya (see Knox et al. 2003, chapter 5, this volume), occurs within the lowermost part of the Esna Shale at the $16 \mathrm{~m}$-level, or $8 \mathrm{~m}$ above of the contact with the Tarawan Chalk. Other details of the biostratigraphy and lithostratigraphy at Dababiya and Qreiya are given in other papers in this volume.

The lower part of the section at Dababiya that includes the Tarawan Chalk and the P/E boundary interval (Dababiya 


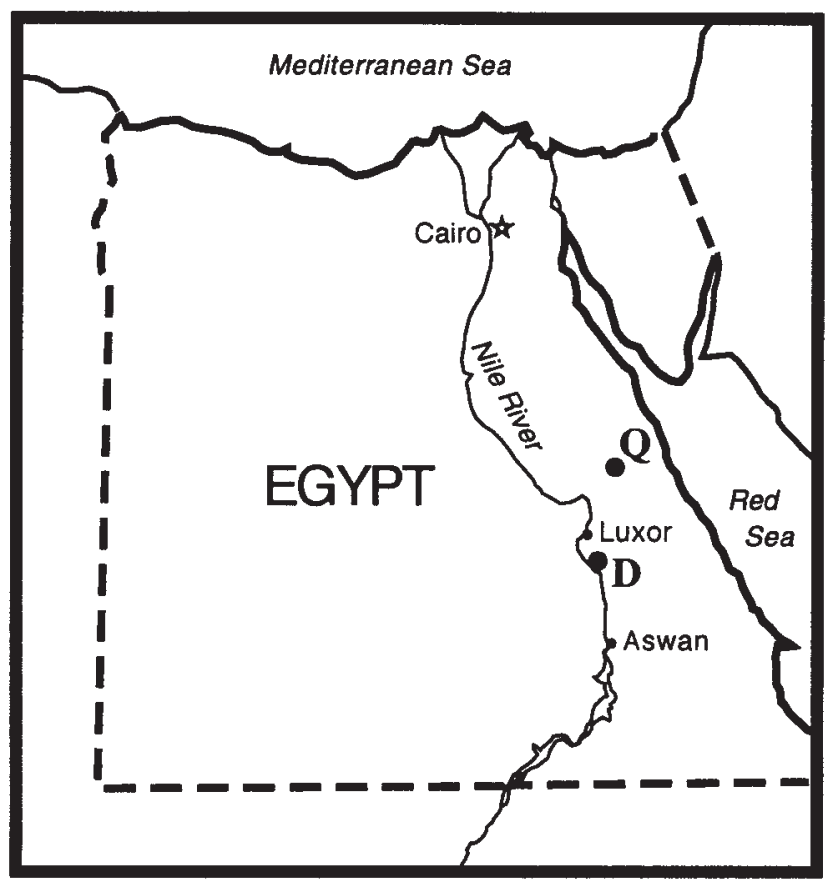

TEXT-FIGURE 1

Location of Dababiya (D) and Qreiya (Q) sampling localities in central Egypt.

Quarry Beds) at the base of the Esna 2 unit was exposed in clean quarry faces and could be sampled directly. Shallow pits were first dug to remove loose and weathered material exposed on hill slopes for the upper parts of the section at Dababiya (Esna 2 and Esna 3 units) and for the entire section on the flanks of the Gebel Abu Had at Qreiya. The Esna and to a lesser extent the Tarawan rocks are not very indurated, which enabled us to take short $2.5 \mathrm{~cm}$-diameter cores with a battery-operated drill using a serrated drill bit operated at low speed without water to avoid disaggregating the sediment. Hand samples were taken where drilling was not possible. All samples were oriented with magnetic compass. The beds at both sampled sections are within a few degrees of horizontal.

In both sections evidence of alteration has to be mentioned. The most obvious marker of it is the widespread distribution of small veins filled with anhydrite. In the Dababiya quarry the good exposures allow us to decipher a slight decrease in the frequency of these alteration features in relation to the distance between the mining extraction front and the initial surface of the outcrops.

Another evidence of alteration or weathering may be found as iron oxide nodules derived from pyrite that are disseminated at some levels in the succession. They are often brown or more rarely red in color and sometimes occur as fossil or burrow molds. Some nodules were subjected to XRD analysis to investigate their mineralogical composition. Red nodules mainly contain hematite, goethite, barite and anhydrite; brown ones contain jarosite, goethite and anhydrite. No pyrite or other sulphides were detected in either type but we cannot exclude that small quantities of primary sulphides and especially pyrite remain partially unaltered locally.
Jarosite, gypsum (anhydrite) and iron oxides are characteristic products of the weathering of primary sulphides and the interaction of sulfuric acid solutions with the surrounding rocks (Nordstrom 1982; De Putter et al. 2000). Anhydrite probably replaces gypsum because of the local climatic conditions of temperature and aridity. Barite may either be a primary sulphate related to organic productivity (Schmitz et al. 1997) or generated under specific geochemical conditions (e.g., base concentration, $\mathrm{pH}$ ) related to acid weathering (Carson et al. 1982).

We can infer that this association of alteration minerals may be more or less regularly present in the whole rock as shown by the in-situ iron oxide epigenesis of pyritized macro- and microfossils. Vein infillings reveal that there was water movement/ circulation able to distribute $\mathrm{Ca}$-sulphate bearing solutions and leading to the precipitation of anhydrite (gypsum). The veins also imply a tectonic context favoring the opening of the fractures. If we suppose that the first sulfate deposited was gypsum, we must postulate a previous phase acting in different climatic conditions (higher precipitation?) followed by a more arid one.

\section{NRM AND IRM DEMAGNETIZATION ANALYSIS}

A total of 112 oriented samples from the Tarawan Chalk and Esna Shale at Dababiya and Qreiya were obtained for paleomagnetic analysis. The natural remanent magnetization (NRM) of each sample was measured on a 2G 3-axis DC-Squid cryogenic magnetometer in a magnetically shielded room. Progressive thermal demagnetization analyses were also done in the shielded room using a custom-built non-inductively wound oven with 3 heating elements and a water jacket to maintain temperature uniformity. Samples were maintained for 45 minutes at each temperature stop and cooled by forced air; residual fields in the oven were less than $10 \mu \mathrm{T}$. Magnetic susceptibility of the samples was measured after each thermal treatment to monitor laboratory-induced magnetochemical alteration. The thermal demagnetization results were displayed on vector end-point diagrams and component directions calculated by principal component analysis over selected temperature steps.

The NRM intensities were on the order of $0.3 \mathrm{~mA} / \mathrm{m}$ for the Tarawan Limestone and $3 \mathrm{~mA} / \mathrm{m}$ for the Esna Shale, with considerable variation. Thermal demagnetization of NRM usually showed straightforward vector end-point diagrams where the removal of a recent viscous or weathering-related component with low unblocking temperature (typically to $100^{\circ}$ or $200^{\circ} \mathrm{C}$ ) was followed by univectorial decay to the origin (text-fig. 2.) This stable magnetization, referred to as component $\mathrm{B}$, typically persists to temperatures of $650-675^{\circ} \mathrm{C}$, which suggests a hematite carrier. The B component has both normal (northerly and down; e.g., text-fig. 2a, c, d) and reverse (southerly and up; e.g., text-fig. 2b, e) polarities in different samples at Dababiya, whereas only a normal polarity B component magnetization was found in the Qreiya samples (text-fig. 2f, g).

Selected fresh samples were subjected to isothermal remanent magnetization (IRM) acquisition and thermal demagnetization analyses to characterize the dominant magnetic carriers. IRM acquisition curves invariably show that saturation remanence is not reached by $2.5 \mathrm{~T}$; median coercivities are typically $0.5 \mathrm{~T}$ to as much as $1.5 \mathrm{~T}$ and signal the presence of magnetic mineralogic phases with very high coercivity (text-fig. 3). In some samples (e.g., text-fig. 3b), there may also be a bench in the lower coercivity range $(\sim 0.2 \mathrm{~T})$ of the acquisition curve, suggesting the presence of an additional, lower coercivity magnetic remanence phase. 


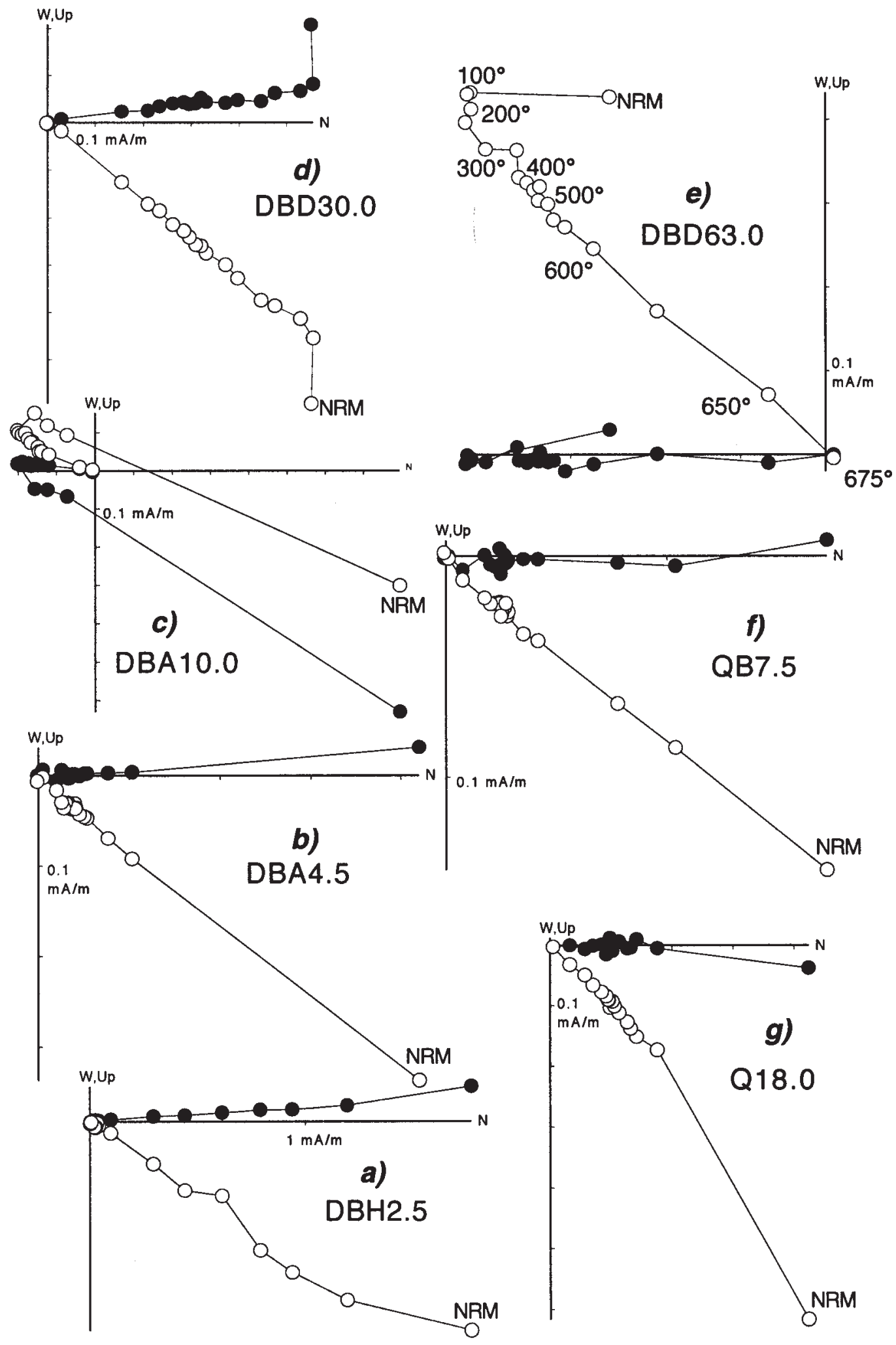

TEXT-FIGURE 2

Vector end point diagrams of thermal demagnetization of NRM of representative samples of Tarawan Chalk and Esna Shale. Open/closed symbols projected on vertical/horizontal planes in geographic coordinates. Thermal demagnetization steps labeled in (e). Dababiya section: a) Tarawan Chalk, b-e) Esna Shale; Qreiya section: f) Tarawan Chalk, g) Esna Shale. 

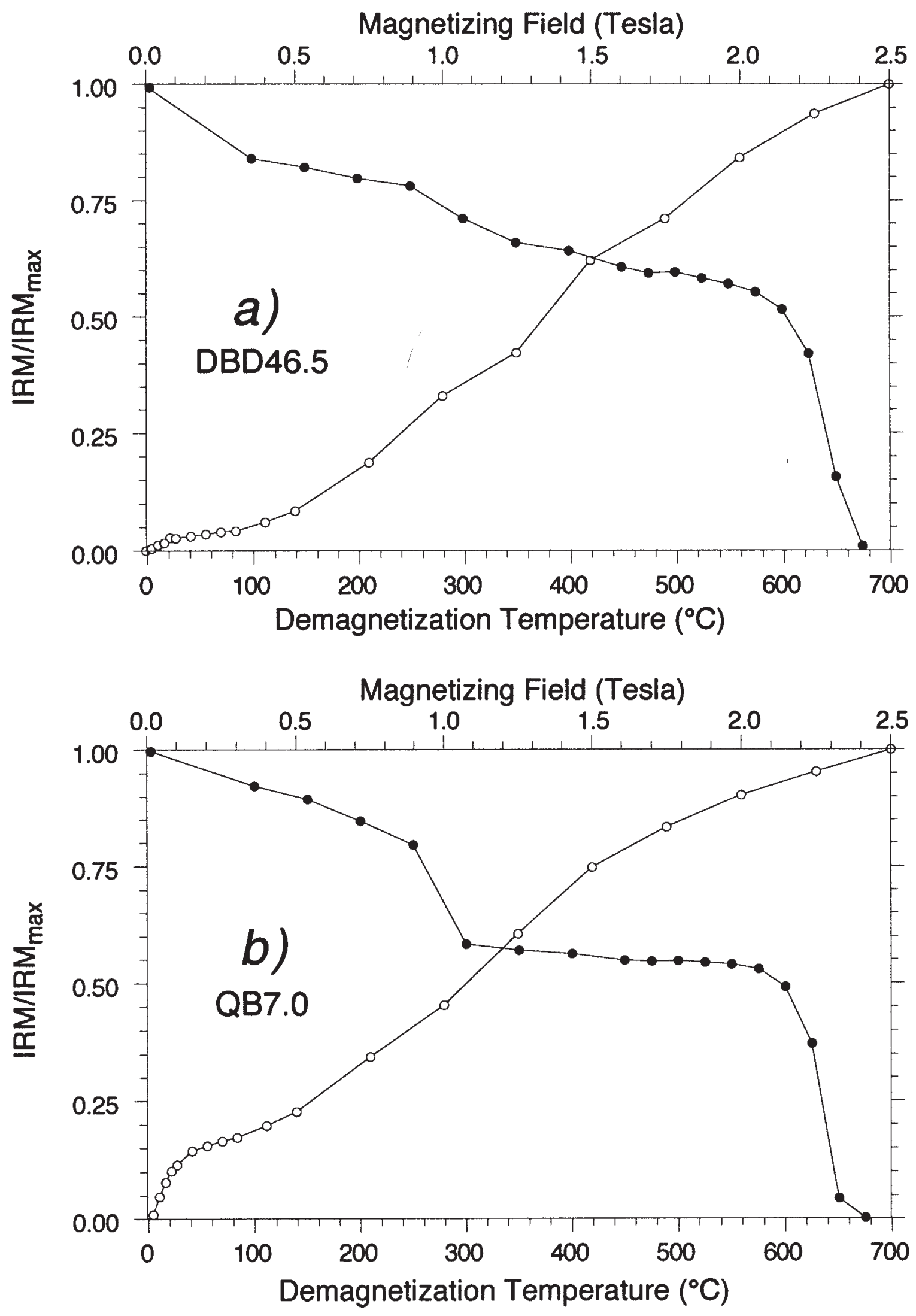

TEXT-FIGURE 3

IRM acquisition (open symbols) and thermal demagnetization (closed symbols) of representative samples of a) Esna Shale and b) Tarawan Chalk. 


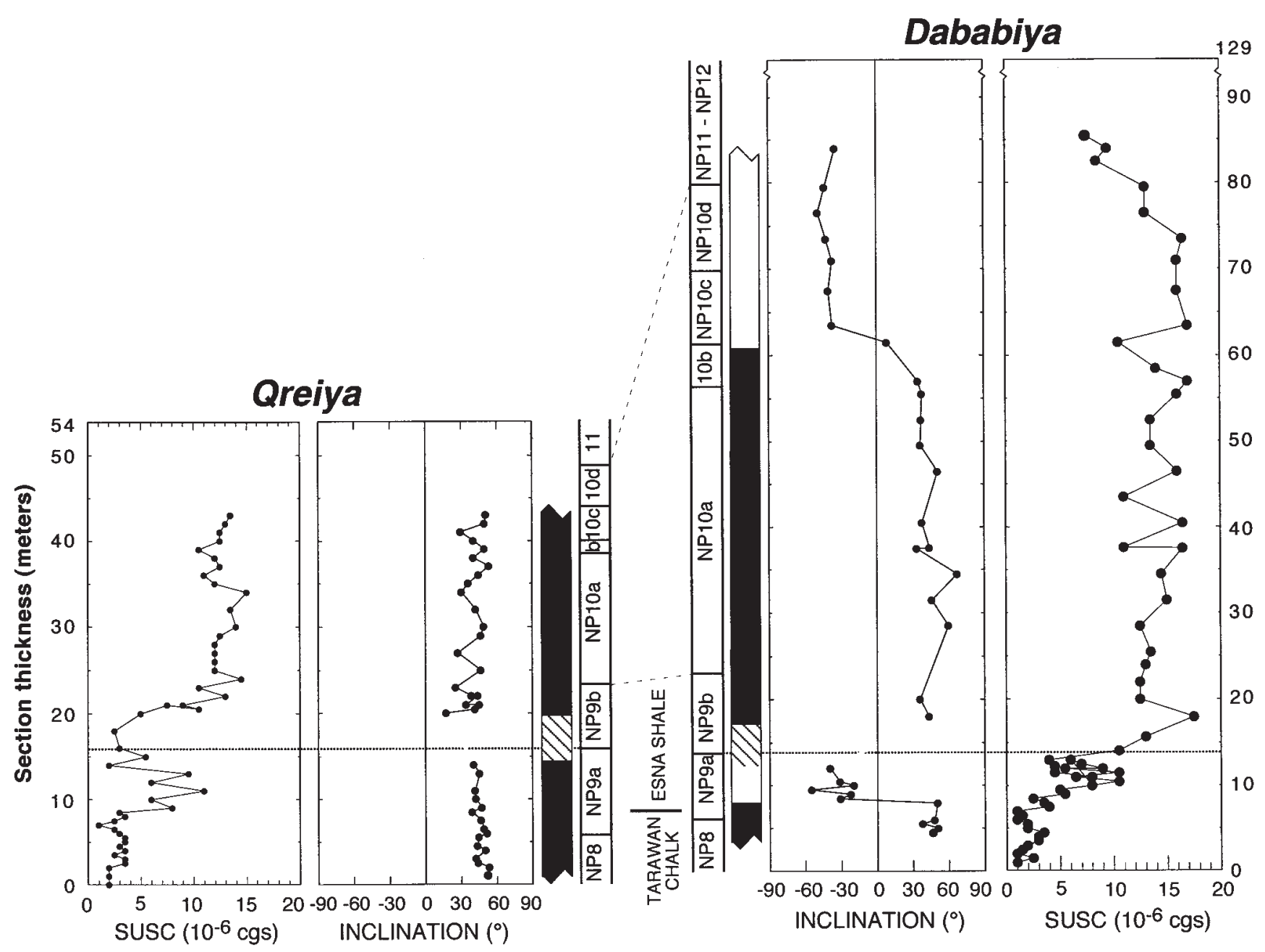

TEXT-FIGURE 4

Magnetic susceptibility and B component inclination as a function of stratigraphic position in the Dababiya and Qreiya sections. Stratigraphic positions of rejected samples that had unstable magnetizations are indicated by ticks on zero inclination axes. Calcareous nannofossil stratigraphy from Dupuis et al. 2003, chapter 3, this volume. Proposed GSSP for the base of the Eocene Series (P/E boundary) is approximated by the nannofossil NP9a/NP9b zonal boundary (14.5m-level in Dababiya and 16.0m-level at Qreiya). The Dababiya and Qreiya sections are aligned according to the contact of the Tarawan Chalk with the Esna Shale, which extends to its contact with the Thebes Limestone at the 54m-level in Qreiya and 129m-level at Dababiya.

Thermal demagnetization of IRM shows a concentration of high unblocking temperatures of $650-675^{\circ} \mathrm{C}$, consistent with similarly high unblocking temperatures of NRM and pointing to hematite as the important carrier of stable remanence in these rocks. There are sometimes steps in the demagnetization curves at around $100^{\circ} \mathrm{C}$ and $300^{\circ} \mathrm{C}$, which can be attributed to goethite and some form of magnetic sulphide like pyrrhotite or griegite, respectively. These magnetic minerals - hematite, goethite and the magnetic sulphide - are usually not associated with a stable primary remanence in marine sediments. Moreover, evidence is lacking for magnetite (i.e., a concentration of IRM or NRM unblocking temperatures at around $575^{\circ} \mathrm{C}$ ). Although the presence of normal and reverse polarities is encouraging for the B component magnetizations to be interpreted as primary, the preponderance of secondary magnetic minerals and the absence of a primary remanence carrier such as magnetite suggest that an early acquisition of these magnetizations is suspect. A further indication that the $\mathrm{B}$ component magnetizations are not closely related to depositional age is that the polarity patterns at
Dababiya and Qreiya are inconsistent with each other and with known global magnetobiostratigraphic relationships.

The B component was successfully isolated in 71 of the samples analyzed from the Dababiya and Qreiya sections. Most of the rejected samples, which showed a very large reduction in magnetization by $200^{\circ} \mathrm{C}$ and no consistent demagnetization trajectory at higher temperature steps, come from the coprolite-bearing interval in the lower part of the Esna Shale in both sections. A stratigraphic plot of the B component inclination in the Dababiya section shows a transition from normal to reverse polarity at the $9 \mathrm{~m}$-level, close to the Tarawan Chalk / Esna Shale contact (text-fig. 4). It would be tempting to correlate this normal to reverse polarity transition, which is a few meters above the NP8/NP9 biozonal boundary, to the Chron $\mathrm{C} 24 \mathrm{r} / \mathrm{C} 25 \mathrm{n}$ reversal. However, a similar polarity transition is not present at the same stratigraphic level at Qreiya where all samples with stable magnetizations have normal polarity directions. More problematical are the thick intervals of normal polarity directions at Dababiya (18m to $61 \mathrm{~m})$ and at Qreiya (19m to $43 \mathrm{~m}$ ), which occur within Biozone NP10 (Dupuis et al. Chap- 


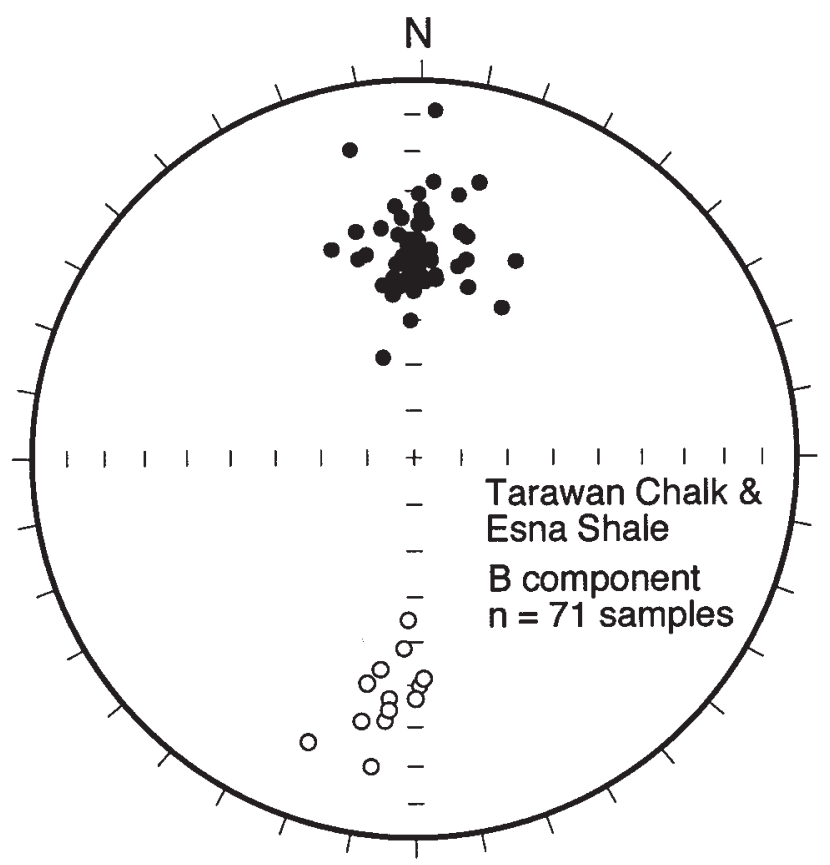

TEXT-FIGURE 5

B component directions obtained from thermal demagnetization of samples from Tarawan Chalk and Esna Shale at Dababiya and Qreiya. Open/closed symbols on upper/lower hemisphere of equal-area projection in geographic coordinates.

ter 3, Knox et al. Chapter 5, this volume) and should thus be within Chron C24r . Reverse polarity directions do occur in the Dababiya section from $63 \mathrm{~m}$ to the top of the sampled section at $85 \mathrm{~m}$, an interval encompassing Subzones NP10b, NP10c, and the lower part of Zone NP11 (text-fig. 4), but there is no reverse polarity counterpart in the biostratigraphic age-equivalent interval at Qreiya, which has only normal polarity directions. It is thus unclear which, if any, of the magnetic polarity intervals at the Dababiya and Qreiya sections provide reliable magnetostratigraphic records.

\section{PALEOPOLES}

The mean northerly $\left(\mathrm{D}=1.1^{\circ} \mathrm{I}=43.6^{\circ}\right)$ and southerly $(\mathrm{D}=$ $\left.186.8^{\circ} \mathrm{I}=-36.8^{\circ}\right) \mathrm{B}$ component sample directions are within $8^{\circ}$ of antipodal and evidently reflect normal and reverse polarity states of an ancient paleomagnetic field (text-fig. 5). An indication of when the B component normal and reverse magnetizations were acquired can be surmised from the mean direction and associated paleopole position. The overall mean direction for the B component from the Dababiya and Qreiya sections obtained after inverting the reverse direction to common normal polarity is $\mathrm{D}=2.2^{\circ} \mathrm{I}=42.4^{\circ}$ (Table 1 ). The corresponding pole position is located at $87.5^{\circ} \mathrm{N} 158.9^{\circ} \mathrm{E}\left(\mathrm{A} 95=2.5^{\circ}\right)$, very close to the present geocentric axial dipole field direction (i.e., the geographic axis). By comparison to the apparent polar wander (APW) path for Africa, the Tarawan+Esna pole falls on the youngest (Pliocene or younger) segment and more than $20^{\circ}$ away from Eocene and Paleocene reference poles (text-fig. 6). This suggests that the $\mathrm{B}$ component magnetization of the Paleocene-Eocene Tarawan Chalk and Esna Shale was acquired some time during the past few million years.

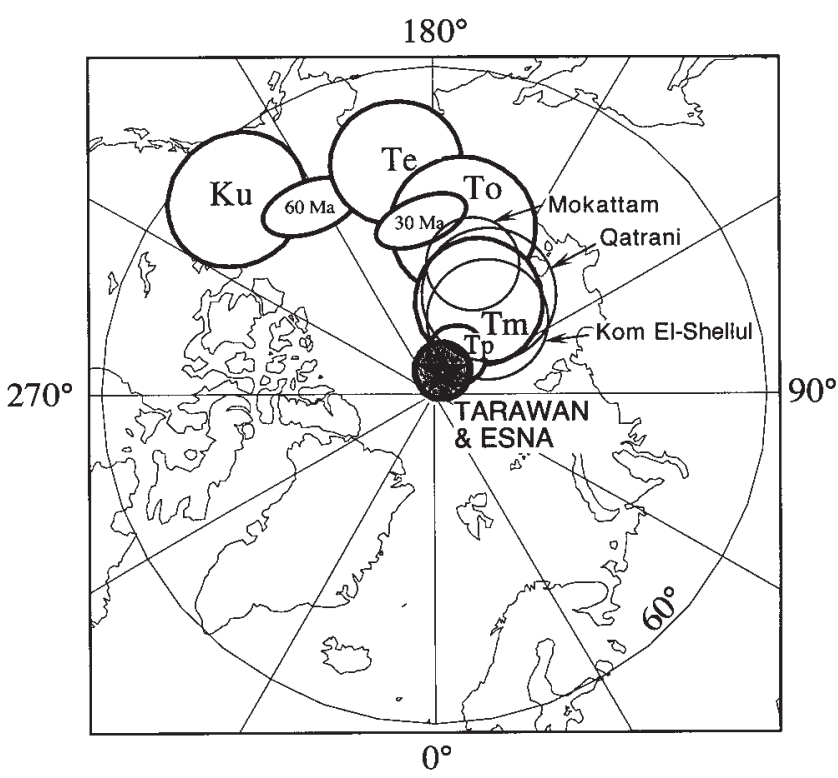

TEXT-FIGURE 6

Paleopole corresponding to the mean B component direction for the Tarawan Chalk and Esna Shale (star; Table 1) compared to reference mean paleopoles for Africa: Ku - Upper Cretaceous; Te-Eocene; To-Oligocene; Tm- Miocene; Tp - Pliocene (compilation of mainly igneous results by Tauxe et al. [1983]; $60 \mathrm{Ma}$ and $30 \mathrm{Ma}$, co-paleolatitude intersection poles using Paleocene and Oligocene inclination-only data from marine pelagic sediments on the African plate (Schneider and Kent 1990). Also shown are paleopoles recently reported from other Cenozoic sedimentary units in the Nile Valley of Egypt (Abdeldayem 1999) from the Eocene Macattam Limestone (m), Oligocene Qatrani Sediments (q) and Pliocene Kom El-Shellul Limestone (k).

\section{DISCUSSION}

Microscopic observations of washed samples from the Esna Shale reveal that benthic and planktonic fauna and other biogenic components are often filled by brownish iron oxide minerals, which evidently resulted from variable alteration of sulphides (pyrite) to jarosite, hematite and goethite. Iron oxide nodules can also be observed in association with jarosite from place to place. In addition, the shales are often hachured by fractures containing a white powder that XRD analysis confirms to be anhydrite. These observations correspond to the detection of sulphides and especially hematite in the NRM and IRM analyses. Sulphides probably formed early in the depositional history of the Tarawan Chalk and especially the Esna Shale, whose overall dark hue is consistent with reducing conditions. Magnetic evidence of residual sulphides was found in the coprolite-bearing interval in the base of the Esna 2 unit (Dababiya Quarry Beds) that did not yield stable magnetizations. However, most of the original sulphides have evidently been altered, especially to the potassium iron sulfate hydroxide mineral jarosite, which is a common alteration product of sulphides in certain weathering environments (e.g., Alpers et al. 1992). The hematite found in these rocks is likely to be associated with the sulphide alteration, even though the Tarawan Chalk and Esna Shale are not red in color. Hematite can carry a stable secondary chemical remanent magnetization, which is the most likely origin of the B component magnetizations. The fact that the secondary $\mathrm{B}$ component has normal and reverse polarities indicates that the alteration to hematite 
proceeded over an extended time interval. The reverse polarity magnetizations provide evidence that at least some if not most of the alteration and weathering was relatively ancient, occurring sometime prior to the Brunhes normal polarity interval (0-0.78 Ma). Ancient episodes of weathering have been documented by ${ }^{40} \mathrm{Ar} /{ }^{39} \mathrm{Ar}$ dating of jarosites elsewhere (Vasconcelos et al. 1994).

The paleomagnetism of several other Cenozoic sedimentary rock units from the Nile Valley (Cairo area) have recently been reported (Abdeldayem 1999): the Eocene Mocattam Limestone, Oligocene Qatrani Sediments, and the Pliocene Kom El-Shellul Limestone. The descriptions of the magnetic properties of these rocks are very similar to those documented here for the Esna Shale and Tarawan Chalk including hematite as a principal carrier of a stable magnetization of both normal and reverse polarity in each unit. Interestingly, the paleopole positions reported for the Mokattam, Qatrani and Kom El-Shellul are not significantly different from each other, despite the range of depositional ages, and are clustered around Miocene and Pliocene reference poles for Africa (text-fig. 6). This suggests that these rock units from the Nile Valley have also been remagnetized although perhaps not precisely at the same time as the Esna Shale and Tarawan Chalk whose pole position falls on the Pliocene and younger portion of the Africa APW path. The remagnetization may be related to initial uplift and rifting of the Nile Valley graben in the Neogene (Said 1993; Mostafa 1999), which may have exposed these rock units to weathering as well as alteration from enhanced fluid migration. In any case, these rocks are dominated by secondary magnetizations and until the remagnetizations can be dated independently, these aleomagnetic results are not very suitable for the construction of APW paths.

\section{ACKNOWLEDGMENTS}

We thank Marie-Pierre Aubry for her leadership of the Paleocene-Eocene GSSP Working Group that instigated this work and brought it to fruition. We also wish to acknowledge the continued financial support by the University of Assiut, and in particular its president, Professor Mohamed R. Mahmoud, of our studies of Paleocene/Eocene sediments in the Upper Nile Valley of Egypt, and our friends and colleagues in the Department of Geology, University of Assiut who have helped with field work logistics, in particular, Professor Khaled Ouda, Professor Ezzat A. Ahmed, Professor Moustafa Youssef, Dr. Nageh Obaid-alla, Dr. Mamdouh F. Soliman, Ayman Abd-El Sabour Ahmed, Wael Fathi Hassan Galal and Dr. Abdel Aziz Tantawy, South Valley University, Aswan. Additional support for this program was made possible through the U.S.-Egypt Science and Technology Joint Fund administered by the US National Science Foundation, International Program Grant. No. 017898 and by the Egyptian Academy of Scientific Research and Technology, Project code OTHS-008-001, Contract No. 140. This is Lamont-Doherty Earth Observatory contribution \#6418.

\section{REFERENCES}

ABDELDAYEM, A.L., 1999. Palaeomagnetism of some Cenozoic sediments, Cairo-Fayum area, Egypt. Physics of the Earth and Planetary Interiors, 110: 71-82.

ALPERS, C.N., R.O., R., NORDSTROM, D.K., WHITE, L.D. and KING, B.S., 1992. Chemical, crystallographic, and isotopic properties of alunite and jarosite from acid hypersaline Australian Lakes. Chemical Geology, 96: 203-226.
TABLE 1

Paleomagnetic directions from Tarawan Chalk and Esna Shale.

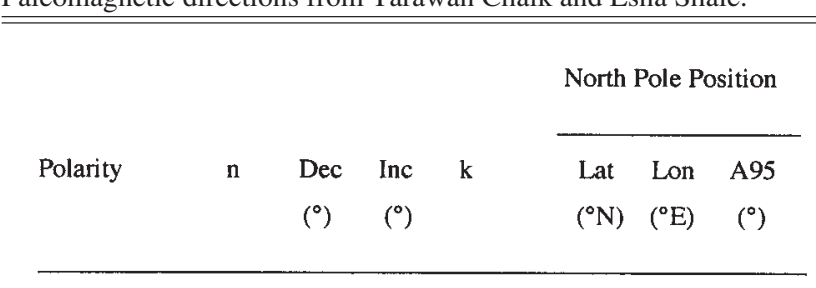

A component $\left(100-200^{\circ} \mathrm{C}\right)$

$\begin{array}{llllllll}\text { Normal } & 72 & 0.9 & 38.1 & 34 & 85.4 & 202.9 & 2.9\end{array}$

B component $\left(550-650^{\circ} \mathrm{C}\right)$

$\begin{array}{lrrrrrrr}\text { Normal } & 58 & 1.1 & 43.6 & 49 & 88.9 & 151.8 & 2.7 \\ \text { Reverse } & 13 & 186.8 & -36.8 & 53 & 81.7 & 162.9 & 5.7 \\ \text { N + R } & 71 & 2.2 & 42.4 & 47 & 87.5 & 158.9 & 2.5\end{array}$

BERGGREN, W.A. and AUBRY, M.-P., 1998. The Paleocene/Eocene epoch/series boundary: Chronostratigraphic framework and estimated geochronology. In: Aubry, M.-P., Lucas, S.G. and Berggren, W.A., Eds., Late Paleocene-Early Eocene Climatic and Biotic Events in the Marine and Terrestrial Records. New York: Columbia University Press, pp. 18-36.

BERGGREN, W.A., KENT, D.V., SWISHER, C.C. and AUBRY, M.P., 1995. A revised Cenozoic geochronology and chronostratigraphy. In: Berggren, W.A., Kent, D.V., Aubry, M.-P. and Hardenbol, J., Eds., Geochronology, Time Scales and Global Stratigraphic Correlations. Society for Sedimentary Geology, Special Publication 54, pp. 129-212.

CANDE, S.C. and KENT, D.V., 1995. Revised calibration of the geomagnetic polarity time scale for the Late Cretaceous and Cenozoic. Journal of Geophysical Research, 100: 6093-6095.

CARSON C.D., FANNING D.S. and DIXON, J.B., 1982. Alfisols and ultisols with acid sulfate weathering features in Texas in Acid Sulfate Weathering, In: Kittrick, J.A., Fanning, D.S. and Hossner, L.R., Eds., Soil Science Society of America Special Publication 10, Madison, Wisconsin, 127-146.

DE PUTTER Th., BERNARD A., PERRUCHOT A., NICAISE D., and DUDUIS Ch., 2000. Low-temperature acid weathering in Newhaven, Sussex, United Kingdom, and its application to theoretical modeling in radioactive waste-disposal sites. Clays and Clay Minerals, 48(2): 238-246.

FLYNN, J.J. and TAUXE, L., 1998. Magnetostratigraphy of upper Paleocene-lower Eocene marine and terrestrial sequences. In: Aubry, M.-P., Lucas, S.G. and Berggren, W.A., Eds., Late Paleocene-Early Eocene Climatic and Biotic Events in the Marine and Terrestrial Records. New York: Columbia University Press, pp. 67-90.

KIRSCHVINK, J.L., 1980. The least-squares line and plane and the analysis of palaeomagnetic data. Geophysical Journal of the Royal Astronomical Society, 62: 699-718.

MOSTAFA, M.S., 1999. Evolution tectonique de la plate-forme africaine en Egypte depuis le Mésozoïque à partir de l'analyse des déformations cassantes. Thèse de doctorat, Mémoires de Sciences de la Terre, Université Pierre-et-Marie-Curie, 325 p., annexes et planches, $97 \mathrm{p}$.

NORDSTROM, K. D., 1982. Aqueous pyrite oxidation and the consequent formation of secondary iron minerals in Acid Sulfate 
Weathering. In: Kittrick, J.A., Fanning, D.S. and Hossner, L.R., Eds., Soil Science Society of America Special Publication 10, Madison, Wisconsin, 37-55.

SAID, R., 1990. Cenozoic. In: Said, R. Ed., The Geology of Egypt. Rotterdam: Balkema, pp. 451-486.

, 1993. Origin and evolution of the River Nile. In: Said, R., Ed., The River Nile, Geology, Hydrology and Utilization. Oxford: Pergamon Press, pp. 1-56.

SCHMITZ B., CHARISI S.D., THOMPSON E.I. and SPEIJER R., 1997, Barium, $\mathrm{SiO}_{2}$ (excess), and $\mathrm{P}_{2} \mathrm{O}_{5}$ as proxies of biological productivity in the Middle East during the Palaeocene and the latest the latest Palaeocene benthic extinction event. Terra Nova, 9, 95-99.

SCHMITZ B., SPEIJER R.P. and AUBRY M.-P., 1996, Latest Paleocene benthic extinction event on the southern Tethyan shelf
(Egypt): Foraminiferal stable isotopic $\left(\delta^{13} \mathrm{C}, \delta^{18} \mathrm{O}\right)$ records. Geology, 24(4): 347-350.

SCHNEIDER, D.A. and KENT, D.V., 1990. Testing models of the Tertiary paleomagnetic field. Earth and Planetary Science Letters, 101: 260-271.

TAUXE, L., BESSE, J. and LA BRECQUE, J.L., 1983. Palaeolatitudes from DSDP Leg 73 sediment cores; Implications for the apparent polar wander path for Africa during the late Mesozoic and Cenozoic. Geophysical Journal of the Royal Astronomical Society, 73: 315-324.

VASCONCELOS, P.M., BRIMHALL, G.H., BECKER, T.A. and RENNE, P.R., 1994. ${ }^{40} \mathrm{Ar} /{ }^{39} \mathrm{Ar}$ analysis of supergene jarosite and alunite: Implications to the paleoweathering history of the western USA and West Africa. Geochimica and Cosmochimica Acta, 58: 401-420. 